CAMP Working Paper Series

No 1/2017

\title{
Oil and Civil Conflict: \\ On and Off (Shore)
}

Jørgen Juel Andersen, Frode Martin Nordvik and Andrea Tesei

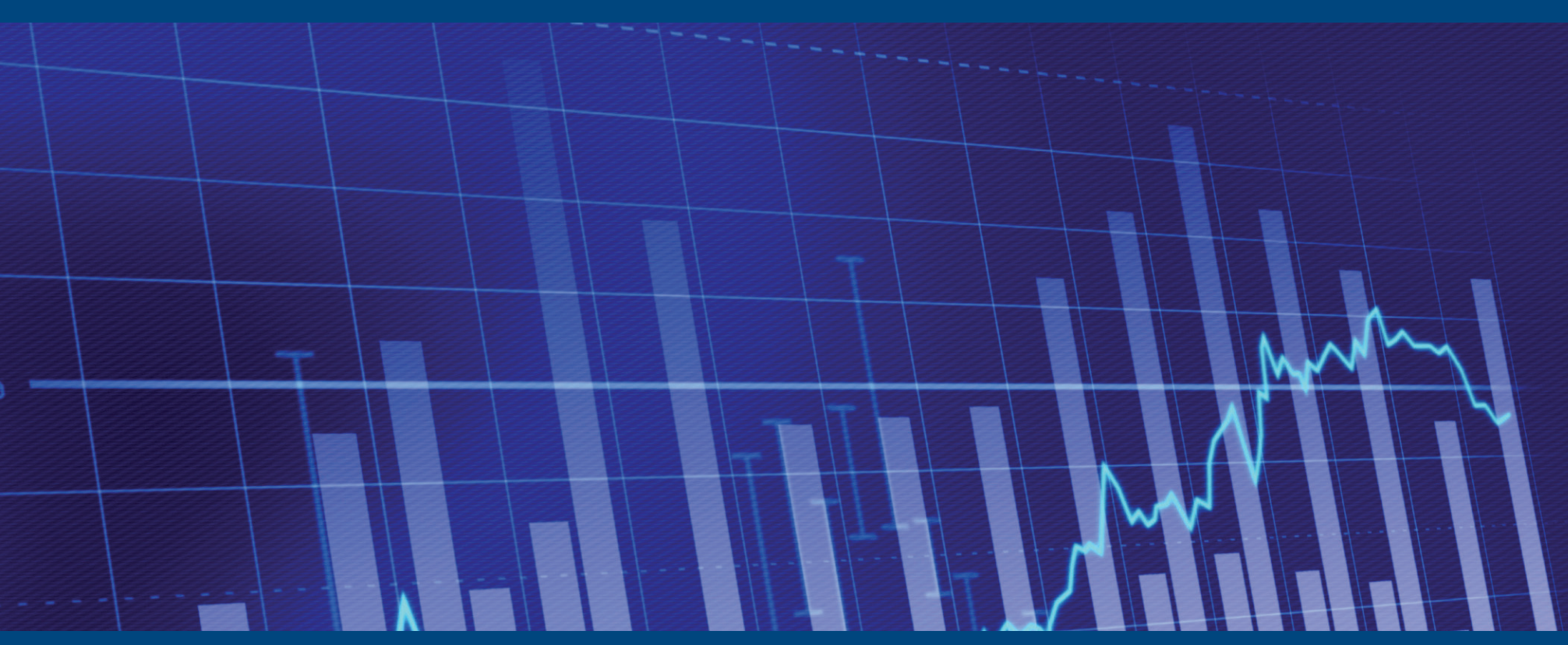

(c) Authors 2017

This paper can be downloaded without charge from the CAMP website http://www.bino/camp 


\title{
Oil and Civil Conflict: On and Off (Shore)*
}

\author{
Jørgen Juel Andersen ${ }^{\dagger} \quad$ Frode Martin Nordvik ${ }^{\ddagger} \quad$ Andrea Tesei ${ }^{\S}$ \\ January 13, 2017
}

\begin{abstract}
We reconsider the relationship between oil and conflict, focusing on the location of oil resources. In a panel of 132 countries over the period 1962-2009, we show that oil windfalls increase the probability of conflict in onshore-rich countries, while they decrease this probability in offshore-rich countries. We use a simple model of conflict to illustrate how these opposite effects can be explained by a fighting capacity mechanism, whereby the government can use offshore oil income to increase its fighting capacity, while onshore oil may be looted by oppositional groups to finance a rebellion. We provide empirical evidence supporting this interpretation: we find that oil windfalls increase both the number and strength of active rebel groups in onshore-rich countries, while they strengthen the government in offshore-rich ones.
\end{abstract}

Keywords: Natural Resources, Conflict

JEL codes: O13, D74, Q34, Q35

\footnotetext{
* We are grateful to Torfinn Harding, Michael Ross, Ragnar Torvik, Thiemo Fetzer and to seminar participants at the NHH-OxCarre Economics of Resource Wealth Workshop in Stavanger (2016) and the Political Economy workshop at the University of Oslo (2015) for many helpful comments. This paper is part of the research activities at the Centre for Applied Macro and Petroleum economics (CAMP) at the BI Norwegian Business School.

$\dagger$ BI Norwegian Business School; contact: jorgen.j.andersen@bi.no

$¥$ BI Norwegian Business School and Centre for Applied Macro- and Petroleum Economics (CAMP); contact: frodemartin@gmail.com

$\S$ Queen Mary University of London, CEP (LSE) \& CEPR; contact: a.tesei@qmul.ac.uk.
} 


\section{Introduction}

Oil is often considered responsible for fuelling civil conflicts - both as a source of funding for the contenders and as a prize for the fighting. Anecdotal evidence consistent with this argument abounds: ISIL's strategic control of resources in Syria and Iraq, oil theft by MEND rebels in Nigeria, attacks to extraction facilities by Darfur insurgents in South Sudan, are only but a few examples of recent oil-related episodes 11 Despite the popularity of the argument, however, establishing a systematic nexus between oil wealth and conflict has proved complex, since oilrich countries display large variations in measures of internal stability. Countries as diverse as Qatar, Norway and Gabon, for example, never experienced a civil conflict over the past 40 years in spite of their vast oil wealth. Other countries, such as Angola and Azerbaijan, even put an end to their conflicts in correspondence to large increases in oil wealth. Indeed, while early cross-sectional studies generally found a positive association between oil wealth and the onset and duration of conflict (Collier and Hoeffler, 2004, Fearon and Laitin, 2003, Le Billon, 2003), more recent studies focusing on within-country variation find mixed evidence on the relationship (Bazzi and Blattman, 2014; Cotet and Tsui, 2013, Lei and Michaels, 2014).

In this paper, we take a fresh look at the oil-conflict nexus by focusing on the location of oil, using new industry-licensed data that allow us to distinguish between onshore and offshore production. We use a large panel of countries and within-country variation to document that onshore and offshore oil have opposite effects on the probability of conflict. While greater onshore wealth increases the probability of experiencing a civil conflict, greater offshore wealth reduces it. To reach these conclusions we use exogenous fluctuations in international oil prices, weighted by each country's average shares of onshore and offshore production. The effects we document are both statistically and economically significant. For a large onshore producer like Iraq, our estimates suggest that a one standard deviation increase in the price of oil raises the probability of conflict by 2.3 percentage points, or $17 \%$ of its mean. For a large offshore producer like Azerbaijan, instead, a similar oil price windfall reduces the probability of conflict by 3.4 percentage points, or $25 \%$ of its mean. In general, we show that the overall impact of oil price windfalls shifts from reducing to increasing the probability of conflict when the share of onshore oil exceeds $60 \%$ of total production.

\footnotetext{
${ }^{1}$ In recent years, the auto-proclaimed Islamic State of Iraq and Levant (ISIL) has repeatedly made the headlines and its financing through oil has been extensively analyzed by the media, see, e.g.: "Inside Isis Inc: The journey of a barrel of oil" (Financial Times, 2015), Other examples of journalistic accounts of sabotage, oil-theft and looting of onshore oil fields in different countries include, but are not limited to, Libya ("Libya Declares Force Majeur Over Oil Fields in Central Region", The Wall Street Journal, 2015), Nigeria ("Renewed Delta violence reignites fears for Nigeria oil production", Financial Times, 2016) and South Sudan ("South Sudan's rebels prepare to attack Paloch oilfields", SSNA, 2015).
} 
We attribute the opposite effect of oil price windfalls in onshore- and offshore-rich countries to their different impact on the fighting capacity of the contenders in the two types of countries. We argue that a crucial difference between offshore and onshore facilities is that the latter can more easily be attacked, looted, and even seized by rebel groups, which in turn can use the proceeds from the looting to finance their conflict activities. Thus, oil price windfalls increase relatively more the fighting capacity of the rebels compared to the government, the larger is the share of onshore oil production for any given share of offshore (or total) oil production in GDP. Conversely, oil price windfalls tilt the balance of power in favour of the government more, the larger is the share of production obtained from offshore facilities, which are easier to defend and whose proceeds almost exclusively accrue to the central government. We document the empirical relevance of the fighting capacity mechanism using a measure of rebel strength relative to the government (Cunningham et al., 2009). Consistent with our explanation, the empirical results indicate that a one standard deviation increase in the price of oil raises the rebels' strength indicator by $55 \%$ of its mean in the average onshore-rich country, while it decreases it by $50 \%$ in the average offshore-rich country.

To get a better sense of the sort of episodes driving our empirical analysis, consider the case of onshore oil-rich Indonesia. During the early 1970s, the discovery of vast oil and gas fields in the northern region of Aceh almost doubled the country's oil production, $80 \%$ of which proceeded from onshore sources. The spike in production, coupled with the fourfold increase in the price of oil during the 1973 crisis, were instrumental to the consolidation of the Free Aceh Movement (GAM). Originally a religious organization, GAM shifted towards insurgency with the aim of securing a larger share of the oil rents to the local population (Schulze, 2006). After a series of both legal and illegal attempts to obtain part of the onshore oil and gas revenues, the group launched an offensive against the central government in 1976.2 During the 1976-1979 period, characterized by soaring oil prices, the number of GAM rebels and their strength relative to the government increased, resulting in a large scale civil conflict. Only around 1980, when oil prices started to decline sharply, did the central government manage to defeat the insurgency, and the group's leader fled the country.

Now consider instead the case of offshore oil-rich Angola, where a major civil conflict between the government in power and the rebels of the National Union for the Total Independence of Angola (UNITA) was ongoing since the country's independence in 1975. During the late 1990s, new technologies of deep water exploration more than doubled the country's offshore production,

\footnotetext{
2 The group's leader, Hasan di Tiro, bid for an oil contract in 1974 but lost to a U.S. company, while in the run-up to the 1976 conflict the group was responsible of numerous episodes of extortion against Exxon Mobil to induce the company to pay "protection fees" for its gas plant in Aceh.
} 
which came to represent $80 \%$ of the country's GDP. The offshore production expansion and the sustained oil price increase (an average growth rate of 60\% per year between 1998 and 2000) played a crucial role in the offensive launched by the government against the rebels in 1999, as the government mortgaged future oil revenues to purchase weapons on the international arms market (Le Billon, 2007). The 1999 offensive resulted in the destruction of the UNITA as a conventional military force, forcing the rebels to return to guerilla tactics. In the following years, thousands more deserted the rebels, finally putting an end to the conflict.

To guide our empirical results, we open the paper with a simple model a la Tullock (1980) in which the incumbent government and a rebel group fight over power and, thereby, the control of oil resources. In the baseline version of the model, the probability of winning the conflict depends on the relative fighting capacity of the contenders. Our simple theoretical innovation is to let the fighting capacities be functions of oil and its geographical location. Crucially, we assume that both onshore and offshore oil income contribute to the fighting capacity of the central government, but only onshore oil contributes to the fighting capacity of the rebels. A straightforward implication of this assumption is that an oil windfall raises the fighting capacity of the rebels relative to the government when the share of onshore production is sufficiently large - that is, above what we call the fighting capacity threshold.

Incorporating the fighting capacity mechanism into the baseline model also allows us to identify an equilibrium conflict threshold. This represents the share of onshore production above which an oil windfall raises the probability of conflict. Notably, the equilibrium conflict threshold lies below the fighting capacity threshold, because it also accounts for the value of holding power (a state prize effect). Hence, the two thresholds effectively identify three ranges for the share of onshore oil production. If the share is low (i.e. below the equilibrium conflict threshold), an oil price shock mostly benefits the government, weakening the rebels and reducing the probability of conflict. If, on the contrary, the share of onshore production is high (i.e. above the fighting capacity threshold), the shock benefits mostly the rebels, raising their fighting capacity and increasing the probability of conflict. Finally, if the share of onshore production lies between the two thresholds, an oil price shock increases the probability of conflict in spite of making the government relatively stronger. Intuitively, this is because - at intermediate values of onshore production - the increased value of holding power (the state prize effect) more than compensate the rebels for the reduced probability of winning the conflict (the fighting capacity effect), motivating them to intensify their conflict activities despite having become relatively weaker compared to the government.

Both the fighting capacity and the equilibrium conflict thresholds depend on parameters that 
may vary across countries. In particular, when onshore facilities are easily lootable or when rebels are more effective than the government in transforming resources into fighting capacity, the share of onshore wealth at which oil windfalls tilt the fighting capacity in favour of the rebels is (potentially much) lower. In this way, the model can also account for cases like Nigeria and Democratic Republic of Congo, where the limited state apparatus hampers the ability to secure onshore facilities and transform oil revenues into military power, making them subject to frequent spikes in rebels' activity and conflict in spite of the limited share of onshore oil production.

The paper continues as follows. Section 2 places our contribution in the related literature. In Section 3, we formulate a simple model and derive the hypotheses that we take to the data. Section 4 describes the data and establishes the empirical model derived from the theory. Section 5 provides the main results from the empirical analysis, while Section 6 concludes.

\section{Related literature}

An early and influential literature in political science and economics investigates the relationship between resource abundance - oil in particular - and civil conflict using predominantly cross-country variation (Le Billon, 2003, Fearon and Laitin, 2003, Collier and Hoeffler, 2004). These studies generally point to a positive relationship between resource abundance and incidence of conflict. More recent studies, however, argue that identification of causal effects can be achieved with greater confidence using within-country variation. When focusing on within-country variation and using exogenous price shocks or resource discoveries for empirical identification, the results are more mixed. Lei and Michaels (2014) find that giant oil discoveries increase the incidence of internal armed conflicts within 4-8 years of discovery. Brunnschweiler and Bulte (2009), Cotet and Tsui (2013), Bazzi and Blattman (2014), instead, do not find a significant association between changes in oil wealth and the probability of conflict. We add on this literature by focusing on the geographical location of oil.

The only studies that we are aware of which explicitly focus on the location of oil to investigate civil conflict are Ross (2006) and Lujala (2010). While Ross (2006) finds no significant effects of oil rents on the duration of conflict, Lujala (2010) shows that conflicts last significantly longer when oil and gemstones are located within the conflict zone. Both studies find that only oil produced onshore is associated with the onset of conflict (see also Ross, 2012). One concern with these studies is that they only measure the extensive margin of production (i.e. they only use indicator variables for onshore and offshore production). More importantly, they do not control for country and time effects, meaning that both time-invariant country characteristics as well 
as global trends potentially related to oil production and conflict are not accounted for in their analysis. Finally, their measure of oil's location is potentially endogenous to the existence of conflict. We overcome these shortcomings by focusing on within-country changes in oil wealth over time, weighting exogenous changes in the international price of oil by the average share of onshore and offshore oil production in GDP.

Our identification strategy is similar to the one used in the literature investigating the effects of income shocks induced by commodity price changes (Brückner and Ciccone, 2010; Berman and Couttenier, 2013; Caselli and Tesei, 2016, Dube and Vargas, 2013). An important distinction in these studies has to do with the extent of capital and labor intensity of different commodities. Dube and Vargas (2013), for example, show that price shocks to the capital-intensive oil sector in Colombia are positively related to violent conflict, while the relationship is negative for the labor-intensive coffee sector. This lends support to the hypothesis that oil income fosters rentseeking behavior by increasing the state prize, while income from coffee triggers an opportunity cost effect by increasing worker wages. Our results show that, besides differences in factor intensity, other characteristics of natural resources contribute to explain their tendency to fuel conflict. We argue in particular that, while onshore and offshore oil are similar in terms of capital intensity, they are asymmetrically appropriable by the two sides in conflict, thus affecting the relative fighting capacities of government and rebels and the ensuing probability of conflict. ${ }^{3}$ This interpretation, based on the different ability of government and rebels to access onshore and offshore oil facilities, echoes similar arguments on the importance of conflict financing (e.g. Fearon, 2004; Collier et al. 2009). This is also in line with recent empirical evidence by Berman et al. (2015), who show that the appropriation of mining revenues by rebel groups contributes to the spreading of conflict to other parts of the country, something the authors attribute to the increased financial ability to sustain larger-scale insurgency.

Our focus on the fighting capacity of the contenders is complementary to other explanations of the impact of oil abundance on conflict. The already mentioned state prize hypothesis suggests that oil abundance increases the probability of conflict by raising the prize that can be seized through the capture of the state (Bates et al., 2002; Fearon and Laitin, 2003). Alternative explanations focus on the lack of incentives for rentier states to develop a strong state capacity, which eventually makes them less able to prevent rebellions (Dunning, 2008, Ross, 2012); and on the inability of incumbent governments to credibly commit to oil rents redistribution, which exacerbate grievances of the excluded groups (Fearon, 2004; Besley and Persson, 2011). While

\footnotetext{
${ }^{3}$ In a similar spirit, Fetzer and Marden (2016) show that contestability of land title is associated to conflict. While their results refer to a form of "institutional lootability", we consider "technical lootability" of natural resources.
} 
these theories aim to explain the incidence of conflict in oil-rich countries, they cannot account for the opposite effect of onshore and offshore oil windfalls on the probability of conflict observed in our data.

Our results are also broadly related to the class of contributions that have investigated the effects of oil price windfalls on political-economy outcomes other than civil conflict. For example, Haber and Menaldo (2011) and Brückner et al. (2012) present empirical evidence on oil abundance and democratization. Caselli and Michaels (2013) and Dalgaard and Olsson (2008) look at oil windfalls and corruption; Andersen and Aslaksen (2013) and Deaton and Miller (1996) at incumbents' survival; and Caselli et al. (2014) at international war.

Finally, our paper relates to Nordvik (2014), who studies the prevalence of coups d'etat in oil rich countries and documents strong asymmetries in the onshore-offshore dimension. While coups and civil conflict are very different processes, our findings confirm that the location of oil may affect the political incentives of both incumbent governments and oppositions.

\section{A theory of onshore versus offshore oil and conflict}

We consider an oil-rich economy where the real value of oil production (or wealth), $R$, is assumed to be linear in the real oil price. Our model's economy is occupied by two groups, the government $G$ and the opposition $O$, who fight over those oil resources that are directly controlled by the government, $R_{G}$. Importantly, the government does not have full control of the entire oil endowment, hence, $\frac{R_{G}}{R}<1$. Specifically, while all of the offshore oil resources are under exclusive government control, a portion $\delta$ of the onshore oil is diverted by the opposition. The parameter $\delta$ is thus a measure of the lootability of the onshore oil resources 4 Denoting the share of oil that is located onshore by $n$, the government's oil share can be expressed as $\frac{R_{G}}{R}=$ $(1-\delta n)$, where the remaining $\frac{R_{O}}{R}=\delta n$ is diverted by the opposition 5

We model the conflict over $R_{G}$ using a Tullock-type conflict framework, where the win probabilities of the two groups depend on their respective conflict powers according to a standard contest function (Hirshleifer, 1991; Skaperdas, 1996). We are interested in particular in how oil price shocks change the conflict intensity in equilibrium, when both the opposition and the

\footnotetext{
4 The parameter $\delta$ can be interpreted as the share of onshore oil that is subject to continuous looting activities (e.g., via oil bunkering of onshore oil pipelines as in the Niger delta) or extortion (as in the case of Colombia, see Stanford University's "Mapping Militant Organizations").

${ }_{5}$ Alternatively, one could assume that some share $\omega$ of the offshore oil is directly or indirectly controlled by rebels. All of our results would go through as long as $\omega<\delta$. Our results are also preserved if we assume, albeit less realistically, that the opposition controls all of the onshore resources while the government controls all of the offshore resources, i.e., $\delta=1$.
} 
government endogenously adjust their conflict efforts ${ }^{6}$

We begin our analysis by setting up and analyzing the baseline conflict model, where a share of the oil is controlled by the opposition. Next, we derive the fighting capacity mechanism, we introduce it into the baseline setup and demonstrate how this changes the conflict equilibrium. Finally, we summarize the main theoretical predictions that we bring to the data, as well as a set of auxiliary results that will become useful when interpreting the empirical results.

\subsection{Baseline model: oil's location and the state prize mechanism}

In a conflict, the win probability for group $i=G, O$ is determined by the following contest success function,

$$
\pi\left(p_{i}, e_{i}\right)=\frac{p_{i} e_{i}}{p_{G} e_{G}+p_{O} e_{O}},
$$

where $p_{i}>0$ is, for now, an exogenous parameter for the conflict power of group $i$, and $e_{i}$ is group $i$ 's endogenously determined fighting effort. For simplicity, we assume that each group can be represented by a representative agent with risk neutral preferences. Group $i$ 's expected payoff from fighting can then be expressed as

$$
\Pi_{i}\left(e_{i}\right)=\frac{p_{i} e_{i}}{p_{G} e_{G}+p_{O} e_{O}}(1-\delta n) R-W e_{i},
$$

where the first term is the expected economic gain and the second term is the expected economic cost for group $i$ of fighting with effort $e_{i}$, given the exogenous opportunity cost of fighting, $W: 7$

The following timing of events describes the game between the government and the opposition:

1. Nature determines the state of the world, given by the vector $[n, \delta, R, W]$.

2. Each group $i$ simultaneously determines its fighting effort $e_{i}$, taking the state of the world and their own and the other group's payoff functions in Eq. 3.2 as given.

3. Payoffs are distributed across the government and the opposition according to the contest success function in Eq. (3.1).

In the resulting game, all the strategic action takes place at Stage 2, where each group $i$ maximizes Eq. (3.2) with respect to $e_{i}$, taking the other group's maximization as given. Since

\footnotetext{
${ }^{6}$ Consistent with our empirical setup, we restrict attention to mechanisms that may be relevant in the short run, while we disregard long-run mechanisms such as changes in investment and exploration policies, political and military strategies, strategic alliance formation, and geo-political dynamics. See Van der Ploeg and Rohner (2012) for a dynamic conflict model on the endogenous determination of both conflict and resource extraction, or Aslaksen and Torvik (2006) for the joint determination of political and conflict equilibria.

7 A standard interpretation of $W$ is that it refers to the real wage rate per unit of effort that can be obtained in the labor market.
} 
the groups' payoff functions are symmetric, the solution to this problem implies fully symmetric equilibrium fighting efforts, $e_{G}=e_{O}=e^{*}$, where

$$
e^{*}=\frac{p_{G} p_{O}(1-\delta n) R}{W} .
$$

The equilibrium fighting effort $e^{*}$, which can be interpreted as the equilibrium conflict intensity, is decreasing in the cost of conflict $W$ - the opportunity cost effect - and increasing in the value of holding office $(1-\delta n) R$ - the state prize effect. Notably, while oil price windfalls raise the equilibrium conflict intensity by raising the value of oil resources $R$, their effect is dampened for larger shares of onshore oil $n$. The intuition for this result is straightforward: the larger is the share of the resources that can be diverted by other groups than the government, the lower is the value of holding office and the less intense is the conflict over controlling the state's resources.

\subsection{The fighting capacity mechanism}

While the state prize mechanism is intuitively appealing - the conflict over state resources should be more intense the larger is the value of these resources and, as discussed above, less intense the larger is the share that can be diverted by the opposition - the baseline model ignores an important feature of economic resources in a conflict economy: resources, whether they come from oil or elsewhere, do not only constitute a motive, but they also provide the means for fighting. In this section, we thus extend the baseline model to allow for the conflict power parameters $p_{G}$ and $p_{O}$ to be endogenous to the value and the location of oil. We assume that the mapping of conflict funding into absolute fighting capacities is given by the functions $f_{i}(\cdot)=f\left(R_{i}+\bar{R}_{i}\right)$, where $R_{i}$ is defined as above, and $\bar{R}_{i}$ refers to the respective groups' exogenous, non-oil conflict funds 8 We further assume that $f_{i}(\cdot)$ are concave, such that $f_{i}(\cdot)>$ $0, f_{i}^{\prime}(\cdot)>0$, and $f_{i}^{\prime \prime}(\cdot)<0$. The concavity captures the notion of diminishing marginal effectiveness of weapons and war equipment: a rebel group represents more of a military threat if it has the funds to purchase one missile battery rather than none, but if it already has ten missile batteries, being able to fund one more presumably contributes less at the margin to its fighting capacity. Hence, if $R_{G}+\bar{R}_{G}>R_{O}+\bar{R}_{O}$ - for example, because the government is well endowed with offshore oil resources or because it is able to raise a significant amount of funds through regular taxation - our assumption about the shape of $f_{i}(\cdot)$ implies that, while

\footnotetext{
8 For example, for the incumbent, $\bar{R}_{G}$ may refer to the non-oil tax income at the economy's fiscal capacity constraint (in which case $W$ should be interpreted as the resulting after-tax wage rate), and for the opposition $\bar{R}_{O}$ may be interpreted as the proceeds from donations, looting, and extortion in other parts of the economy than the oil sector.
} 
the government is military stronger than the opposition, one additional dollar of funding for each of the two parties results in a sharper increase in the fighting capacity of the opposition than that of the government.9

We can then define the relative fighting capacities of the government and the opposition that is, their respective conflict powers - as:

$$
p_{i}(\cdot)=\frac{f_{i}(\cdot)}{f_{G}(\cdot)+f_{O}(\cdot)}
$$

Note that the relative fighting capacities in Eq. (3.4) are endogenous to the location and the value of oil, as $f_{i}(\cdot)$ are functions of $n$ and $R$. For notational convenience, in the continuation we use $p_{i} \equiv p_{i}(\cdot)$.

When analyzing this fighting capacity model, as well as in our analysis of the conflict equilibrium later, the following assumption will be useful:

\section{ASSUMPTION 1: $p_{G}>1 / 2$}

Assumption 1 states that the relative fighting capacity of the incumbent is larger than that of the opposition. This seems consistent with observations of the real world, where in most cases the state apparatus provides a series of war funding instruments that are not available to the opposition. It is also easy to see how realistic assumptions about the values of the parameters $n$ and $\delta$ yield Assumption 1 endogenously. For example, even if there are no offshore resources (i.e., $n=1$ ), and even if the base funding of the two groups is identical (i.e., $\bar{R}_{G}=\bar{R}_{O}$ ), one only needs to assume that no more than half of the onshore resources are lootable (i.e., $\delta<1 / 2$ ) for Assumption 1 to hold endogenously ${ }_{10}^{10}$ For later use, however, it appears convenient to state the inherent incumbency advantage explicitly, as in Assumption 1.

We are now ready to characterize the first key feature of our model, namely how the relative fighting capacity of the government (i.e., one minus that of the rebels) responds to a change in the price of oil, and how this comparative static relates to the key parameters of the model. Taking the derivative of Eq. (3.4) with respect to $R$, we get

$$
p_{G_{R}}^{\prime}=1-p_{O_{R}}^{\prime}=\left[1-\delta\left(1+\gamma_{O G}\right) n\right]\left(1-p_{G}\right) p_{G} \varepsilon_{G_{R}}
$$

where (with a slight abuse of notation, suppressing the arguments of the function $\left.\varepsilon_{G_{R}}\right) \varepsilon_{G_{R}} \equiv$ $f_{G_{R}}^{\prime} / f_{G}(\cdot)>0$ is a measure of how responsive the fighting capacity of the government is to

\footnotetext{
9 While the concavity of $f_{i}(\cdot)$ is intuitively appealing, it is not necessary for our main results. These only require that $f_{i}(\cdot)$ are positive and increasing.

${ }^{10}$ In most cases it also seems reasonable to assume that $\bar{R}_{G}$ is much larger than $\bar{R}_{O}$, implying that Assumption 1 will hold even for very high values of the lootability parameter $\delta$ (i.e., $\delta$ close or equal to 1 ).
} 
a change in the government's conflict funds, and where $\gamma_{O G} \equiv \varepsilon_{O_{R}} / \varepsilon_{G_{R}}>0$ is a measure of the fighting capacity effectiveness of the opposition relative to that of the government. It is straightforward to see from Eq. 3.5 that the effect of an oil price shock on the relative fighting capacities of the incumbent and the opposition is ambiguous and crucially depends on the sign of the term $\left[1-\delta\left(1+\gamma_{O G}\right) n\right]$.

Defining the fighting capacity threshold of the onshore share $\bar{n}$ as

$$
\bar{n}=\frac{1}{\delta\left(1+\gamma_{O G}\right)},
$$

we have that:

$$
\left.\begin{array}{l}
p_{G_{R}}^{\prime} \lesseqgtr 0 \\
p_{O_{R}}^{\prime} \gtreqless 0
\end{array}\right\} \quad \text { iff } n \gtreqless \bar{n} .
$$

Eq. (3.7) shows that an increase in a country's oil wealth raises the fighting capacity of rebels when these have large onshore resources to draw from. On the contrary, when a country's oil wealth is mostly located offshore, the oil revenues accrue for the most part to the central government, whose relative conflict power increases. We summarize the results on the fighting capacity effect of an oil price shock in the following proposition:

PROPOSITION 1 Under Assumption 1, an oil price windfall: (i) increases the fighting capacity of the government relative to the opposition if the share of onshore oil in the economy is sufficiently small, that is if $n<\bar{n}$; (ii) increases the fighting capacity of the opposition relative to the government if the onshore oil share is sufficiently large, that is if $n>\bar{n}$.

Proposition 1 states that if the share of onshore oil is below the fighting capacity threshold $\bar{n}$, oil windfalls tilt the balance of power in favour of the government. In isolation, since the government is already the stronger side in conflict (by Assumption 1) and oil windfalls make it even stronger, this should dampen the conflict intensity. However, this reasoning ignores the fact that oil windfalls also raise the prize from conflict and therefore may induce rebels to fight the government, despite their relative power having decreased. To account for this state prize effect, in the continuation we therefore study the overall equilibrium effect of oil price windfalls by incorporating the fighting capacity mechanism into the standard conflict model of section (3.1). 


\subsection{The fighting capacity mechanism in conflict equilibrium}

Using the fact that $p_{O}=1-p_{G}$, substituting the expression for $p_{G}$ in Eq. (3.4) into the conflict equilibrium in Eq. (3.3), and taking the derivative of the conflict equilibrium with respect to $R$, we get

$$
e_{R}^{* \prime}=\frac{\left(1-2 p_{G}\right) p_{G_{R}}^{\prime}(1-\delta n) R+p_{G}\left(1-p_{G}\right)(1-\delta n)}{W} .
$$

The expression in Eq. (3.8) describes how an oil price windfall affects the equilibrium conflict intensity. The second term in the numerator of the expression represents the state prize effect (at the given power balance $p_{G}\left(1-p_{G}\right)=p_{G} p_{O}$ ), while the first term is the fighting capacity effect (at the given state prize $\left.(1-\delta n) R=R_{G}\right)$. As discussed above, the state prize effect of an oil windfall is always positive, albeit decreasing in the onshore share due to looting. However, the fighting capacity effect is ambiguous and depends on the sign of $p_{G_{R}}^{\prime}$ (see Proposition 1).

Let $\underline{n}$ be the equilibrium conflict threshold of the onshore share, defined as

$$
\underline{n}=\left[1+\frac{1}{\left(1-2 p_{G}\right) \varepsilon_{G_{R}} R}\right] \bar{n}
$$

(where $\underline{n}<\bar{n}$ since, by Assumption 1, $\frac{1}{\left(1-2 p_{G}\right) \varepsilon_{G_{R}} R}<0$ ). We then have that:

$$
e_{R}^{* \prime} \gtreqless 0 \quad \text { iff } \quad n \gtreqless \underline{n} .
$$

We summarize the results on the equilibrium conflict effect of an oil price windfall in the following proposition:

PROPOSITION 2 Under Assumption 1, an oil price windfall: (i) decreases the equilibrium conflict intensity if the share of onshore oil in the economy is sufficiently small, that is if $n<\underline{n}$; (ii) increases the equilibrium conflict intensity if the onshore oil share is sufficiently large, that is if $n>\underline{n}$.

While Proposition 2 states that oil price windfalls increase the probability of conflict if the share of lootable onshore resources is sufficiently large (i.e., if $n>\underline{n}$ ), the most interesting result in the proposition is perhaps that oil price windfalls may also decrease the incidence of civil conflict. To see that there exists an equilibrium where oil price windfalls have negative conflict effects (i.e., that we may have $n<\underline{n}$ ), note that the term $\varepsilon_{G_{R}} R$ in Eq. (3.9) may be arbitrarily large depending on the exact shape of the concave fighting capacity function $f_{G}(\cdot)$. Evaluating Eq. (3.9) in the limiting case where $\varepsilon_{G_{R}} R \longrightarrow \infty$ - that is, when the government's 
fighting capacity is strongly (infinitely) responsive to changes in $R$ - the equilibrium conflict threshold converges to the fighting capacity threshold $(\underline{n} \longrightarrow \bar{n})$, which is positive for any value of $\delta \in(0,1]$ and $\gamma_{O G}>0$.

\subsection{Main predictions and auxiliary results}

The above theory suggests several regularities that we expect to find in the data. The two main hypotheses that we empirically test are the following:

H1 There exists an equilibrium conflict threshold $\underline{n}$ for the onshore oil share, such that the conflict effect of an oil price windfall is (i) negative if the onshore share is below this threshold and (ii) positive if the onshore share is above it.

H2 There exists a fighting capacity threshold $\bar{n}$ for the onshore oil share, such that the effect of an oil price windfall on the fighting capacity of the rebels relative to the government is (i) negative if the onshore share is below this threshold and (ii) positive if the onshore share is above it.

In addition to the two main predictions above, our theory can further help us interpret the data in a number of ways. First, by comparing our empirical estimates of the thresholds in H1 and H2, we may infer which of the two mechanisms - the fighting capacity or the state prize - is more relevant in driving the conflict effects of oil price windfalls. If the equilibrium conflict threshold $\underline{n}$ turns out to be strictly lower than the fighting capacity threshold $\bar{n}$, this suggests that the conflict may escalate even if an oil price shock reduces the relative strength of the rebels, implying that the state prize mechanism dominates over the fighting capacity mechanism for intermediate values of the onshore share (between the two thresholds). If, on the contrary, the two thresholds are empirically indistinguishable, this suggests that the conflict effects of windfalls are driven by the fighting capacity mechanism. Second, the estimate of the fighting capacity threshold $\bar{n}$ may inform us about the effectiveness of the rebels relative to the government in transforming an oil income shock into fighting capacity, $\gamma_{O G}$. In particular, from Eq. 3.6 we have that $\gamma_{O G}=\frac{1}{\bar{n} \delta}-1$. By substituting our empirical estimate of the fighting capacity threshold $\bar{n}$ in this expression, we may infer the range of $\gamma_{O G}$ for plausible values of the parameter $\delta$. 


\section{Data and empirical specification}

We construct measures of onshore and offshore petroleum intensity using data from Rystad Energy's UCube database (2013). Rystad is an independent oil and gas consulting services company headquartered in Oslo, Norway, which collects production data from oil and gas companies' annual reports as well as authorities' historical production accounts. Based on their data, we calculate for each country the average share of onshore and offshore oil production in GDP over the sample period 1962-2009. We check the quality of the Rystad Energy data against the total share of oil production in GDP from the World Development Indicators and find a correlation of 0.99 between the two measures.

We interact these country-specific weights of onshore and offshore production with oil price data from the BP Statistical Review of World Energy 11 We proceed under the assumption that annual changes in the oil price are stationary, but that the oil price in levels follows a random walk. This is in line with previous studies (Liang and McDermott, 1999, Brückner et al., 2012) and is confirmed by a variety of tests of stationarity on our oil price series 12

The conflict data come from the UCDP/PRIO Armed Conflict Dataset. Civil conflict is defined for armed confrontations resulting in at least 25 battle-related deaths in a year, while the threshold for civil war is set at 1,000 battle-related deaths. We complement this information with data on the relative strength of rebel groups from the Non-State Actor database (Cunningham et al. 2009). The dataset provides information on the military capabilities of non-state actors relative to the government in ongoing civil conflicts in the UCDP/PRIO dataset. The rebel strength indicator ranges from 0 to 5 (from non-active to much stronger than the government) ${ }^{13}$ Governments may be facing contemporaneous conflict dyads with different rebel groups. For each conflict-year we calculate the average and maximum strength of rebel groups as well as their number.

The simple cross-country association between the location of oil and conflict can be appreci-

11 Price is money-of-the-day, as the correlation between real and nominal percentage changes in the price in this period is $99.7 \%$. Data are available at www.bp.com.

12 First, an augmented Dickey Fuller test fails to reject the null hypothesis that the series contains a unit root. Second, since unit root tests have notoriously low power against competing alternative (Cochrane, 1991) we complement it with the Kwiatkowski test for time-series stationarity, which rejects the null at the 95\% confidence level. Finally, the Lo-MacKinlay test, which more specifically tests for the time series being a random walk, fails to reject the null at conventional levels. All three tests therefore indicate, under alternative null hypotheses, that the oil price series in levels is best characterized as a random walk process. Applying the same tests on the first-difference of the oil price series gives evidence against a unit root at the $99 \%$ confidence level, and strongly indicates that the first-difference of the oil price is stationary.

13 There are only about 20-25 recorded cases in our data where the rebels are coded as stronger than the government (i.e., where the rebel strength variable takes on the values 4 or 5 ), which amounts to less than $3 \%$ of the total number of conflict observations $(=850)$. That the government is usually stronger than the rebels in civil conflicts is consistent with our Assumption 1 in the theory model. 
ated in Figure 1, which ranks the 20 oil producers (at least $3 \%$ of GDP) with the highest civil conflict incidence over the period 1962-2009: 13 out of the top 20 conflict countries (and 8 out of the top 10) have their oil facilities located mainly onshore. This pattern is consistent with the hypothesis that onshore oil is more conducive to conflict, although there are clearly many unobserved characteristics that might be driving the relationship.

Key summary statistics for the full sample of countries are reported in Table 1. The average share of total oil in GDP is $6.4 \%$, roughly two thirds of which come from onshore production $(4.0 \%)$ and the remainder from offshore production (2.4\%). The total number of oil producing countries is 87 , two thirds of which (59 countries) produce mainly or only from onshore sources, with the remaining 28 countries producing mainly or only from offshore sources. The geographic distribution of onshore and offshore producers in the sample is illustrated by a world map in Figure 2. Civil war happens in $2.9 \%$ of all country-years observations, while civil conflict is relatively more common, occurring in $13.7 \%$ of total observations. The average civil conflict incidence is higher for onshore-producing countries (22\%) than for offshore-producers (13\%). Table 1 also details the average number of rebel groups faced by the government $(0.31$, ranging from 0 to 11) and their average strength according to the relative strength indicator $(0.31$, ranging from 0 to 5). The latter is higher for onshore oil producing countries (0.43) than for offshore oil producers (0.29).

In order to investigate the effect of oil windfalls on the probability of conflict accounting for the extent of onshore and offshore production, we specify the following dynamic panel data model:

$$
y_{i t}=\beta_{0} y_{i t-1}+\beta_{1} \theta_{i}^{\text {ons }} \Delta \operatorname{Pr}_{t}+\beta_{2} \theta_{i}^{\text {off }} \Delta P r_{t}+\mu_{i}+\delta_{t}+e_{i t}
$$

where $y_{i t}$ is an indicator variable for the incidence or the onset of conflict (or an ordinal variable for the relative strength of rebels), $\theta_{i}^{o n s}$ and $\theta_{i}^{o f f}$ are country-specific average shares of onshore and offshore oil production in GDP, $\Delta P r_{t}$ is the growth rate of the oil price from year $t-1$ to year $t$, and $\mu_{i}$ and $\delta_{t}$ are full sets of country and year fixed effects. We also control for the one-year lagged conflict to account for the inherent persistence of conflict (Nunn and Qian, 2014). Finally, $e_{i t}$ is an error term clustered at the country level. The specification captures that the impact of international oil price shocks, if any, might be stronger in countries where onshore and offshore oil production constitute a larger share of GDP. Based on the theoretical discussion in section 3.2 we should expect $\beta_{2}<0$ and $\beta_{1}>0$, while the existing literature on oil income shocks and conflict implicitly assumes that $\beta_{1}=\beta_{2}$. 


\section{Empirical results}

\subsection{Main conflict results}

Table 2 investigates the impact of oil price windfalls on the onset and incidence of civil conflicts. In columns (1) and (2), we start by weighting oil price windfalls by total oil in GDP. This effectively corresponds to a constrained version of model 4.1), where we allow oil price shocks to have a different impact on conflict depending on the country's oil wealth, but do not account for the location of the oil production (i.e., we assume $\beta_{1}=\beta_{2}$ ). Consistent with previous studies, the resulting oil shock estimates are close to zero and statistically insignificant, suggesting that changes in the oil wealth per se has a weak or nil effect on the probability of civil conflict. In columns (3) and (4), we introduce locational heterogeneity by allowing the coefficients $\beta_{1}$ and $\beta_{2}$ to be different. As predicted by our theory, the estimates reveal a heterogeneous response to oil price windfalls in onshore and offshore producing countries. A one standard deviation increase in the price of oil raises the probability of conflict incidence by $1.5 \%$ for countries at the average level of onshore production, while it reduces it by $1.4 \%$ for countries with average offshore production. ${ }^{14}$ These estimates suggest large effects in times of big oil price hikes and in countries where oil represents a larger share of the economy. For example, a $30 \%$ increase in the price of oil - similar to the situation around the onset of the Gulf war (1990) and during the aftermath of the financial crisis (2011) - is associated with an increase in the probability of conflict of $18 \%$ for large onshore producers like Iraq and to a reduction of $24 \%$ for large offshore producers like Azerbaijan 15 Similar effects are found with respect to civil conflict onset. Based on the estimates in column (3), a one standard deviation increase in the price of oil raises the probability of conflict onset by $7.1 \%$ for average onshore producers and reduces it by $4.6 \%$ for average offshore producers.

Clearly, many countries produce a combination of both onshore and offshore oil. It is therefore interesting to calculate the threshold at which the conflict effect of oil windfalls turns from negative to positive, corresponding to the equilibrium conflict threshold $\underline{n}$ in our theory. Based on the results in column (4), we calculate this threshold to be at about $60 \%$ of onshore oil in total production. ${ }^{16}$ If the share of onshore oil exceeds this threshold, the effect of an oil price shock is to increase the probability of conflict. Conversely, if the onshore share is below $60 \%$, the

\footnotetext{
14 These figures are based on the estimates in column (4) and are calculated as $[(0.292 \times 0.04 \times 0.178) / 0.137]$ and $[(0.292 \times 0.024 \times 0.276) / 0.137]$.

15 Iraq's onshore oil share is $45 \%$ of GDP, while Azerbaijan's offshore share of GDP is $40 \%$.

${ }^{16}$ In the empirical model, Eq. 4.1), the threshold is defined as the level of $n$ at which the marginal effect of a price change is zero, such that $\beta_{1} n+\beta_{2}(1-n)=0$. This implies $\underline{n}=-\beta_{2} /\left(\beta_{1}-\beta_{2}\right)$. Using our estimates of $\beta_{1}$ and $\beta_{2}$ from Table 2, Column (4), we thus have $\underline{n}=[0.276 /(0.276+0.178)] \approx 0.6$.
} 
net effect of an oil price shock is to decrease the probability of conflict. Countries with a share of onshore production above the threshold include conflict-ridden ones like Syria, Sudan, Libya, Iraq and Chad, while countries below the threshold include relatively stable oil-rich countries like Azerbaijan, Cameroon, Qatar and Mexico.

Our main conflict results in columns (1)-(4) are based on OLS estimation. Because this is a dynamic panel model with fixed effects, there arises a natural concern with Nickell bias (Nickell, 1981). To address this concern, column (5) shows results using system-GMM estimation (Blundell and Bond, 2000). The system-GMM results are very close to the original OLS results. ${ }^{17}$ Tests for first- and second-order autocorrelation in the coefficients hint at a proper specification. Although we continue to present both OLS and system-GMM results throughout the paper, our discussion emphasizes the OLS estimates.

In Table 3, we investigate the empirical relevance of the fighting capacity mechanism central to our model. Column (1) starts by showing that the relative strength of the rebels vis-à-vis the government is a significant predictor of the probability of civil conflict. As expected, stronger rebel forces are more likely to engage in a conflict to topple the incumbent government: a onepoint increase in the rebel strength indicator raises the probability of civil conflict by $23 \% 18$ Next, we investigate how the relative strength of parties in conflict is affected by oil price shocks. We consider different measures of strength: in column (2) we calculate the average strength of all rebel groups, in column (3) the strength of the strongest group and in column (4) the number of rebel groups. Irrespective of the measure considered, the estimated coefficients are in line with the predictions of our theoretical model: oil price windfalls increase the number and strength of rebel groups relative to the government in onshore-rich countries, while they reduce it in offshore-rich countries. Based on the estimates in column (2), for example, a one standard deviation increase in the price of oil raises the relative strength of the rebels by 0.26 points, or $85 \%$ of the mean value, in big onshore producers like Iraq. For offshore oil-rich countries like Azerbaijan, on the contrary, a similar oil price shock reduces the strength of the rebels vis-à-vis the government by 0.21 points, or $68 \%$ of the mean value. The results in column (4) also suggest that an increase in the value of lootable onshore resources not only benefits existing rebel groups but also induces new groups to enter the conflict, perhaps by providing them with access to the resources needed to set up an army.

Also in this case, we can calculate the share of onshore production above which oil windfalls raise the relative strength of the rebels against the government (i.e., the fighting capacity

\footnotetext{
17 This should be expected, given the large $\mathrm{T}=48$ in our panel.

18 Note, however, that the relationship arises almost mechanically in the data, since the Non-State Actor database is coded only for episodes of civil conflict.
} 
threshold $\bar{n}$ in our model). The estimates in column (2) indicate that when more than $52 \%$ of total oil production is extracted onshore, the overall effect of an oil price shock is to tilt the balance of power in favour of the rebels. This threshold is exceeded by 35 out of 132 countries in our sample. ${ }^{19}$

We can also calculate, based on Eq. (3.6), the relative effectiveness of governments and rebels in transforming the extra revenues generated by oil windfalls into fighting capacity. This is captured in our model by the parameter $\gamma_{O G}$. Figure 3 plots all combinations of the calculated $\hat{\gamma}_{O G}$ and $\delta$ (the lootability parameter) that are consistent with the conflict-capacity threshold $\bar{n}=0.52$ estimated in the data. Two patterns deserve mention. First, for a plausible range of values of $\delta$, the estimates suggest that the opposition is much more effective than the government in translating its resources into fighting capacity. Second, the downward-sloping relationship between $\hat{\gamma}_{O G}$ and $\delta$ indicates that the less lootable is onshore oil (i.e., the lower is $\delta$ ), the more effective rebels must be in transforming funding into fighting capacity for the model to be consistent with the data 20

Finally, note that our estimates of the fighting capacity and equilibrium conflict thresholds for the onshore oil share cannot be statistically distinguished at conventional levels of significance. Both thresholds lie roughly in the neighborhood of 50-60\%. Following our discussion in Section (3.4), this suggest that the fighting capacity mechanism is the main driver behind our empirical results, while the state prize mechanism appears to be less relevant.

Table 4 investigates the effect of oil price windfalls on the probability of civil war in onshoreand offshore-rich countries. Almost by definition, a civil war implies that the government is relatively weaker and the opposition relatively stronger than in a civil conflict. Our data on rebel strength confirms this notion: the mean of the rebel strenght indicator is about 1.7 across the conflicts that have not escalated into war and about 2.1 in the wars. One way to operationalize this observation in our model is to think of cases where $p_{G} \longrightarrow 1 / 2$. Clearly, when the balance of power between government and rebels is more even, the value of holding power (i.e. the state prize effect) becomes relatively more important in the decision to fight ${ }^{21}$ This in turn implies that the equilibrium conflict threshold $\underline{n}$ should be lower, and that oil price windfalls should be more conducive to civil war at any onshore and offshore oil shares. Although less precisely estimated, the empirical results in Table 4 broadly support this notion. In particular,

19 Counting only countries which have an oil share in GDP of at least $1 \%$.

20 For example, if half of the onshore oil is lootable $(\delta=0.5)$, our empirical estimate of the threshold at 0.52 implies that rebels are about three times as effective at transforming their conflict funding into fighting capacity. If $20 \%$ of the oil is lootable, our estimates suggest that rebels must be nine times as effective as the government.

21 In our model, this can be seen in Eq. [3.8, where the state prize term $p_{G}\left(1-p_{G}\right)(1-\delta n)$ becomes larger as $p_{G} \longrightarrow 1 / 2$. 
the estimated coefficients in columns (3) and (4) confirm that oil price windfalls increase the probability of civil war in countries with larger shares of onshore production. At the same time, differently from smaller scale civil conflicts, larger shares of offshore production (and the associated fighting capacity of the government) do not appear to deter rebels from fighting a full-blown civil war when the value of being in power increases. Indeed, the coefficient of the offshore-weighted oil price shock is statistically insignificant and very close to zero. This suggests that when the stakes are sufficiently high, the state prize effect dominates over the potentially conflict-moderating effect of greater offshore oil being in government control.

\subsection{Robustness checks}

In this section, we check the robustness of our results to: (i) accounting for the potentially endogenous location of oil production; (ii) using alternative criteria for inclusion in the sample based on importance of oil in the economy; (iii) dropping large oil producers with the potential of influencing the world price; (iv) dropping countries where onshore and offshore oil shares are identified with relatively low accuracy.

First, both the level and the composition of oil production may be endogenous to conflict, and the direction of endogeneity bias may go in either direction. For example, a government may want to boost production in order to finance the conflict, or the conflict may directly damage oil infrastructure so as to reduce the output. Moreover, a government may strategically decide to move from onshore to offshore oil production in a period of conflict, in order to avoid rebel attacks and looting of the onshore installations. Or, conflict may tilt oil operations towards the less technically advanced onshore production by deterring foreign direct investment in the more technically advanced offshore industry. To some extent, these concerns will be taken care of by the country fixed effects in our baseline regressions, which effectively controls for any unobserved variation in average conflict at the country level. This, however, does not eliminate the possibility that the oil characteristics may be endogenous to conflict, and it also does not account for the possibility that different countries have embarked on different conflict paths for unobserved reasons that are not captured by our regressions. We try to address these concerns in Table 5 In columns (1) and (2), we replace the average production weights (i.e., the $\theta$ 's) by initial measures of onshore and offshore production in GDP, dated back to 1962. Fixing the weights at the initial sample-year may to a larger extent capture the country's natural predisposition to oil exploitation, and these weights are also constructed prior to any conflicts that take place during our sample period. Columns (3) and (4) instead revert to the baseline specification but also include country-specific linear trends. This accounts for the possibility 
that countries may have embarked on different conflict paths due to omitted trends in variables that may correlate with oil production (e.g., institutional or economic development). In columns (5) and (6) we weigh observations by country population to ensure that the results are not driven by a few small countries' conflict experiences. None of these alterations significantly change the baseline results, which continue to show opposite and statistically significant effects of onshore and offshore income shocks on the probability of conflict.

Second, in Table 6 we check the robustness of our results to the exclusion of very small and very big producers. Since non-oil producing countries and countries with very low shares of oil production in GDP are unlikely to be affected by oil price changes, focusing on a smaller sample of countries with significant oil shares is arguably a better test of our model. At the other end of the spectrum, a concern might be that our results are driven by a limited number of major oil producers, whose expected future political developments have the potential to affect the international oil prices. Columns (1) and (2) exclude non-oil producers, which represent one third of countries in our sample. The point estimates remain very similar to the baseline specification, confirming that our main results are not spuriously driven by non-oil producing countries. In columns (3) and (4) we perform a more stringent test, excluding any countryyear observation in which total production accounts for less than $5 \%$ of GDP. This amounts to including all observations for large producers, plus medium-size producers in years of significant oil production or periods when the oil price level is relatively high. Despite the considerable sample reduction - the remaining sample only includes one third of all observations - the results remain similar to the baseline specification. Finally, in columns (5) and (6) we exclude from the sample all countries belonging to OPEC. The estimates remain qualitatively similar, although in this case the effect of onshore oil becomes marginally insignificant.

Finally, the results in Table 7 demonstrate that our results are robust to controlling for various data quality issues. Columns (1) and (2) include only countries for which the average share of oil production is calculated over more than half of the sample-years. As some countries only report few years of onshore and offshore data, their average production intensity weights may be poorly identified. Columns (3) and (4) restrict the sample to countries for which we observe onshore and offshore shares at least once before 1986, which is the mid-point of the sample period. Finally, columns (5) and (6) show the results when excluding observations with a discrepancy of more than $25 \%$ between the total share of oil in GDP calculated from our data and the corresponding value from the WDI. The results from all these checks remain similar to the baseline estimation. 


\section{Conclusion}

In this paper, we re-examine the relationship between oil wealth and conflict, focusing on the location of oil production. We start from the observation that onshore and offshore oil facilities may be asymmetrically appropriated by the parts in conflict: while offshore oil wealth mainly accrues to the government, onshore facilities can more easily be attacked, looted, and even seized by rebel groups, which in turn can use the proceeds from the looting to increase their fighting capacity. We formalize this insight in a standard conflict model a la Tullock (1980), modified to account for the endogenous fighting capacity of the opponents. The model predicts that an exogenous increase in oil wealth tilts the balance of power in favour of the rebels when the share of onshore production in a country exceeds a certain threshold. When, instead, the share of onshore production is below this threshold, an increase in oil wealth raises relatively more the fighting capacity of the government compared to the rebels. In conflict equilibrium, this fighting capacity mechanism interacts with the state prize mechanism, implying an equilibrium conflict threshold for the onshore-to-total oil production that is above the fighting capacity threshold due to the state prize effect. We demonstrate that the equilibrium conflict threshold exists, and that an oil price shock decreases (increases) conflict if the onshore oil share is below (above) this threshold.

Our empirical results from a large panel of countries support these predictions: exogenous spikes in the price of oil on international markets appear to increase the probability of conflict in onshore-rich countries and to reduce it in offshore-rich ones. We also provide evidence consistent with our interpretation of the results, by showing that changes in the relative fighting capacity of rebels and governments depend on the location of oil. Finally, by aggregating over the onshore and offshore effects of oil price windfalls, we show that the two almost exactly offset each other in the aggregate data, plausibly explaining the zero average effect of oil wealth on conflict found in recent studies. Altogether, our results suggest that the location of natural resources determines who benefit the most from their proceeds so as to explain the resources' tendency to either fuel or deter conflict. A key mechanism is that the resource proceeds affect the fighting capacities of, and thereby the balance of power between, the opponents. 


\section{References}

Andersen, J. J. and S. Aslaksen (2013). Oil and political survival. Journal of Development Economics 100(1), 89-106.

Aslaksen, S. and R. Torvik (2006). A theory of civil conflict and democracy in rentier states. The Scandinavian Journal of Economics 108(4), 571-585.

Bates, R., A. Greif, and S. Singh (2002). Organizing violence. Journal of Conflict Resolution $46(5), 599-628$.

Bazzi, S. and C. Blattman (2014). Economic shocks and conflict: Evidence from commodity prices. American Economic Journal: Macroeconomics 6(4), 1-38.

Berman, N. and M. Couttenier (2013). External shocks, internal shots: the geography of civil conflicts. Review of Economics and Statistics (0).

Berman, N., M. Couttenier, D. Rohner, and M. Thoenig (2015). This mine is mine! how minerals fuel conflicts in africa.

Besley, T. and T. Persson (2011). The logic of political violence. The Quarterly Journal of Economics.

Blundell, R. and S. Bond (2000). Gmm estimation with persistent panel data: an application to production functions. Econometric reviews 19(3), 321-340.

Brückner, M. and A. Ciccone (2010). International commodity prices, growth and the outbreak of civil war in sub-saharan africa. The Economic Journal 120(544), 519-534.

Brückner, M., A. Ciccone, and A. Tesei (2012). Oil price shocks, income, and democracy. Review of Economics and Statistics 94(2), 389-399.

Brunnschweiler, C. N. and E. H. Bulte (2009). Natural resources and violent conflict: resource abundance, dependence, and the onset of civil wars. Oxford Economic Papers 61 (4), 651-674.

Caselli, F. and G. Michaels (2013). Do oil windfalls improve living standards? evidence from brazil. American Economic Journal: Applied Economics 5(1), 208-38.

Caselli, F., M. Morelli, and D. Rohner (2014). The geography of inter-state resource wars. The Quarterly Journal of Economics.

Caselli, F. and A. Tesei (2016). Resource windfalls, political regimes, and political stability. Review of Economics and Statistics 98(3), 573-590.

Cochrane, J. H. (1991). A critique of the application of unit root tests. Journal of Economic Dynamics and Control 15(2), 275-284. 
Collier, P. and A. Hoeffler (2004). Greed and grievance in civil war. Oxford economic papers 56(4), 563-595.

Collier, P., A. Hoeffler, and D. Rohner (2009). Beyond greed and grievance: feasibility and civil war. Oxford Economic Papers 61(1), 1-27.

Cotet, A. M. and K. K. Tsui (2013). Oil and conflict: What does the cross country evidence really show? American Economic Journal: Macroeconomics 5(1), 49-80.

Cunningham, D. E., K. S. Gleditsch, and I. Salehyan (2009). It takes two: A dyadic analysis of civil war duration and outcome. Journal of Conflict Resolution.

Dalgaard, C.-J. and O. Olsson (2008). Windfall gains, political economy and economic development. Journal of African Economies 17(suppl 1), 72-109.

Deaton, A. and R. Miller (1996). International commodity prices, macroeconomic performance and politics in sub-saharan africa. Journal of African Economies 5(3), 99-191.

Dube, O. and J. F. Vargas (2013). Commodity price shocks and civil conflict: Evidence from colombia. The Review of Economic Studies 80(4), 1384-1421.

Dunning, T. (2008). Crude democracy: Natural resource wealth and political regimes, Volume 7. Cambridge University Press Cambridge.

Fearon, J. D. (2004). Why do some civil wars last so much longer than others? Journal of Peace Research 41(3), 275-301.

Fearon, J. D. and D. D. Laitin (2003). Ethnicity, insurgency, and civil war. American Political Science Review 97(01), 75-90.

Fetzer, T. and S. Marden (2016). Take what you can: property rights, contestability and conflict.

Haber, S. and V. Menaldo (2011). Do natural resources fuel authoritarianism? a reappraisal of the resource curse. American Political Science Review 105(01), 1-26.

Hirshleifer, J. (1991). The technology of conflict as an economic activity. The American Economic Review, 130-134.

Le Billon, P. (2003). Fuelling war: Natural resources and armed conflicts. Number 373. Routledge.

Le Billon, P. (2007). Drilling in deep water: oil, business and war in angola. Oil Wars, 100.

Lei, Y.-H. and G. Michaels (2014). Do giant oilfield discoveries fuel internal armed conflicts? Journal of Development Economics 110, 139-157. 
Liang, M. H. and M. C. J. McDermott (1999). How persistent are shocks to world commodity prices? International Monetary Fund.

Lujala, P. (2010). The spoils of nature: Armed civil conflict and rebel access to natural resources. Journal of Peace Research 47(1), 15-28.

Nickell, S. (1981). Biases in dynamic models with fixed effects. Econometrica: Journal of the Econometric Society, 1417-1426.

Nordvik, F. M. (2014). Does oil promote or prevent coups?

Nunn, N. and N. Qian (2014). Us food aid and civil conflict. The American Economic Review 104(6), 1630-1666.

Ross, M. (2006). A closer look at oil, diamonds, and civil war. Annu. Rev. Polit. Sci. 9, 265-300.

Ross, M. (2012). The oil curse: how petroleum wealth shapes the development of nations. Princeton University Press.

Schulze, K. E. (2006). The conflict in Aceh: struggle over oil? Oil Wars, Pluto Press.

Skaperdas, S. (1996). Contest success functions. Economic theory 7(2), 283-290.

Tullock, G. (1980). Efficient rent-seeking. Toward a Theory of Rent Seeking Society, ed. by J. M. Buchanan, R. D. Tollison, and G. Tullock.

Van der Ploeg, F. and D. Rohner (2012). War and natural resource exploitation. European Economic Review 56(8), 1714-1729. 
Figure 1 Civil Conflict and the Location of Oil

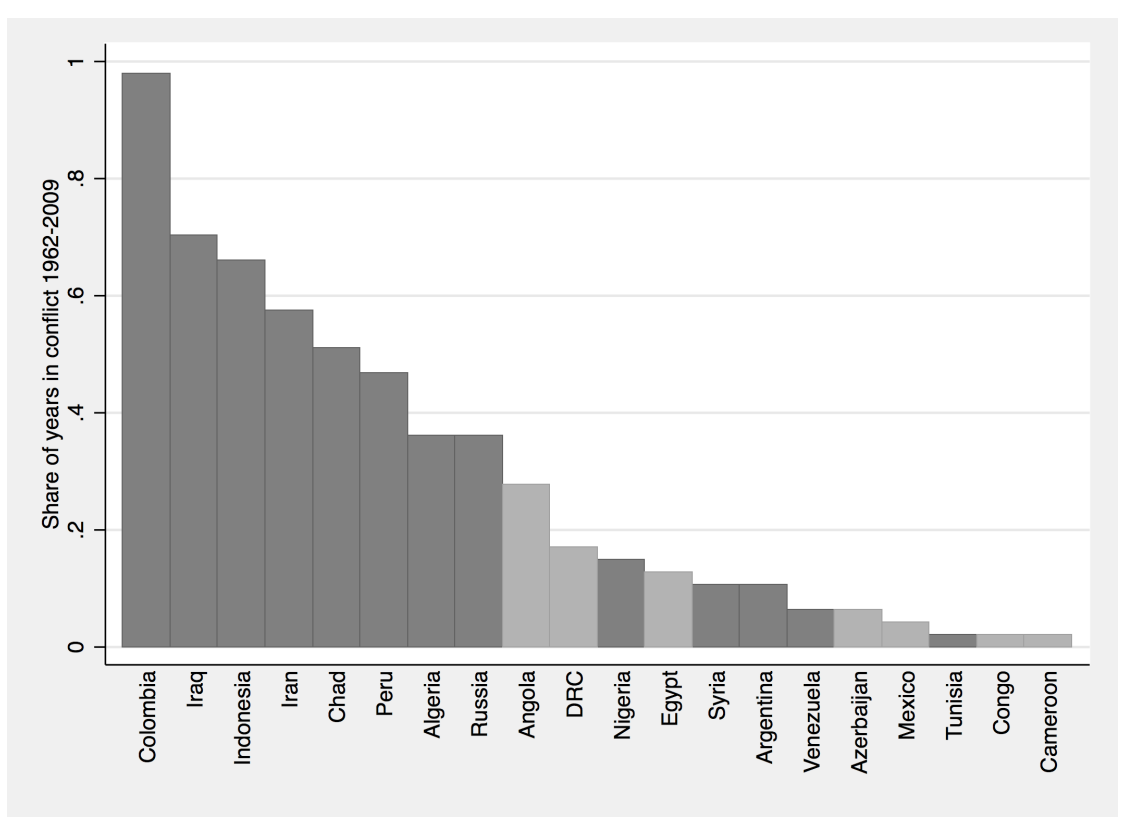

Note: The Figure ranks the 20 oil producers with the highest incidence of civil conflict over the period 1962-2009. Dark grey bars represent countries with mainly onshore production, while light grey bars represent countries with mainly offshore production.

Figure 2 Onshore and offshore oil countries

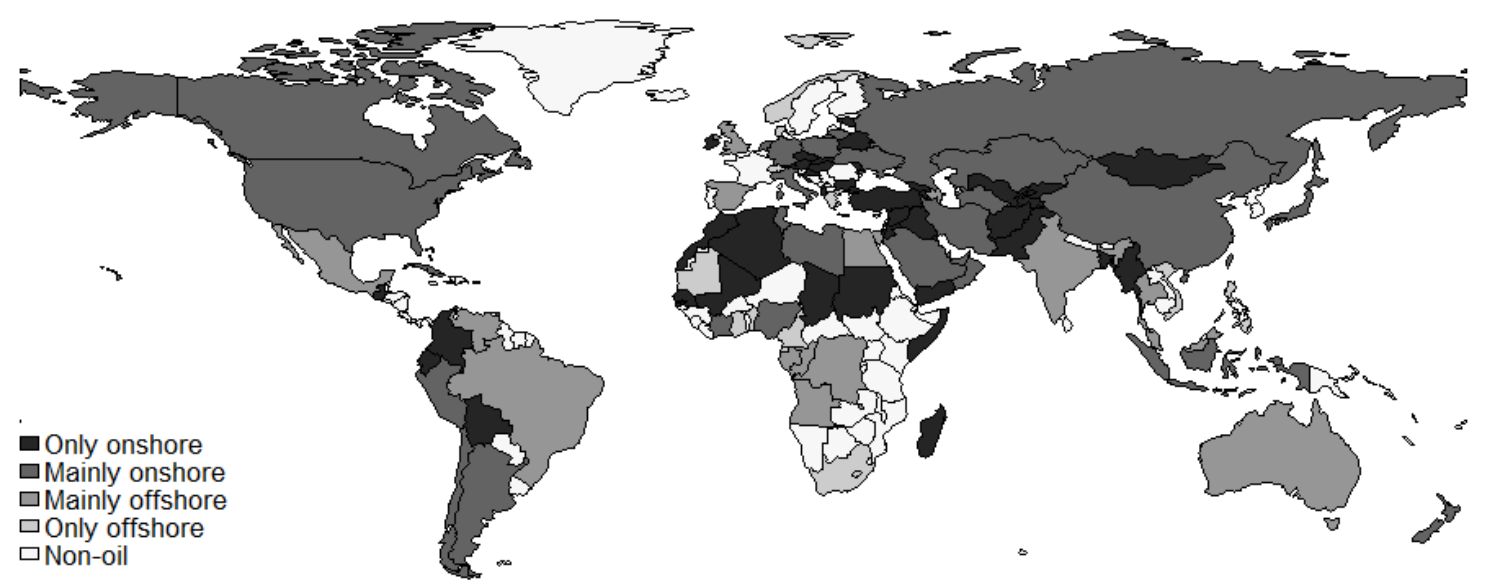

Note: The Figure shows the geographical distribution of onshore and offshore producers. The data come from Rystad Energy (2014). Mainly onshore (offshore) refers to countries with more than $50 \%$ of oil production coming from onshore (offshore) sources. 
Figure 3 Estimated fighting capacity effectiveness of opposition relative to government, $\hat{\gamma}_{O G}$, as a function of oil's lootability, $\delta$.

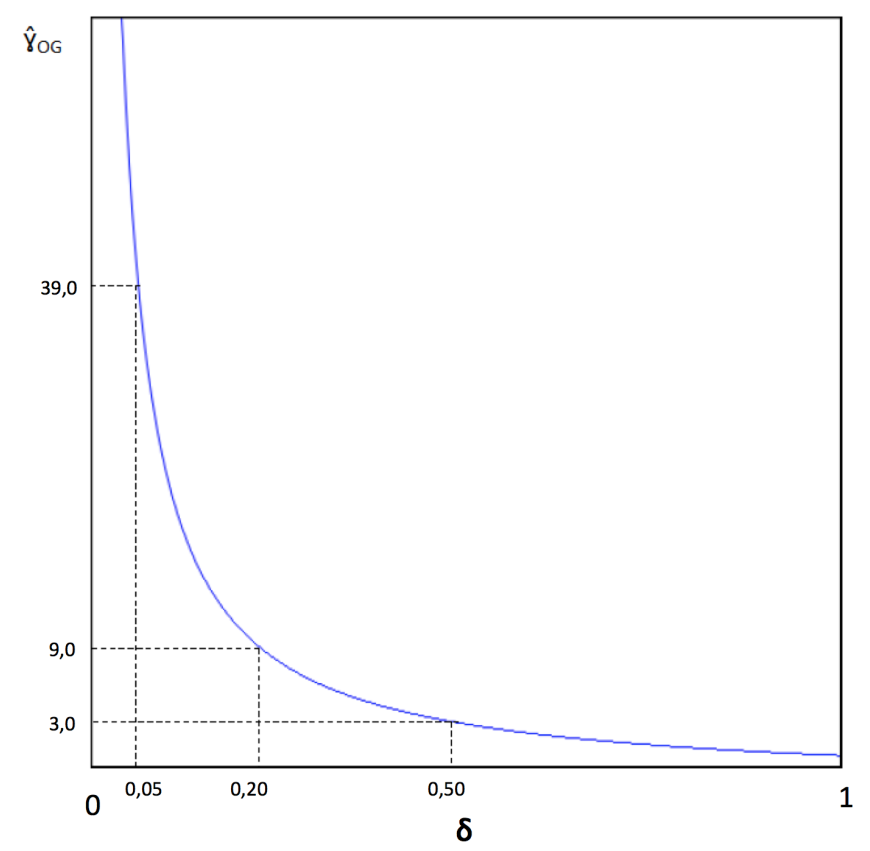

Note: The Figure plots the relationship between $\hat{\gamma}_{O G}$ and $\delta$, using the empirically estimated fighting capacity threshold in total oil, $\bar{n}=0.52$.

Table 1 Summary Statistics

\begin{tabular}{lrlrl}
\hline & Mean & s.d. & Min & Max \\
\hline Total oil share & 0.064 & 0.13 & 0 & 0.596 \\
Onshore share & 0.04 & 0.096 & 0 & 0.512 \\
Offshore share & 0.024 & 0.076 & 0 & 0.583 \\
Oil price \% change & 0.075 & 0.292 & -0.647 & 1.258 \\
War incidence & 0.029 & 0.168 & 0 & 1 \\
Conflict onset & 0.025 & 0.156 & 0 & 1 \\
Conflict incidence & 0.137 & 0.344 & 0 & 1 \\
Conflict incidence (onshore) & 0.220 & 0.414 & 0 & 1 \\
Conflict incidence (offshore) & 0.130 & 0.334 & 0 & 1 \\
N ${ }^{\circ}$ rebel groups & 0.312 & 0.921 & 0 & 11 \\
Rebel strength & 0.311 & 0.748 & 0 & 5 \\
Rebel strength (onshore) & 0.434 & 0.805 & 0 & 4 \\
Rebel strength (offshore) & 0.286 & 0.746 & 0 & 5 \\
\hline
\end{tabular}


Table 2 Oil Price Shocks, Location of Production, and Civil Conflict

\begin{tabular}{|c|c|c|c|c|c|}
\hline & (1) & $(2)$ & $(3)$ & $(4)$ & $(5)$ \\
\hline & LS & LS & LS & LS & SYS-GMM \\
\hline & $\begin{array}{l}\text { Conflict } \\
\text { Onset }\end{array}$ & $\begin{array}{l}\text { Conflict } \\
\text { Incidence }\end{array}$ & $\begin{array}{c}\text { Conflict } \\
\text { Onset }\end{array}$ & \multicolumn{2}{|c|}{$\begin{array}{l}\text { Conflict } \\
\text { Incidence }\end{array}$} \\
\hline$\Delta P r *$ Total & $\begin{array}{c}0.055 \\
(0.059)\end{array}$ & $\begin{array}{l}-0.002 \\
(0.088)\end{array}$ & & & \\
\hline$\Delta P r *$ Onshore & & & $\begin{array}{l}0.156^{*} \\
(0.090)\end{array}$ & $\begin{array}{c}0.178^{* *} \\
(0.087)\end{array}$ & $\begin{array}{c}0.144^{*} \\
(0.083)\end{array}$ \\
\hline$\Delta P r * O f f s h o r e$ & & & $\begin{array}{c}-0.099 * * \\
(0.044)\end{array}$ & $\begin{array}{c}-0.276^{* *} \\
(0.111)\end{array}$ & $\begin{array}{c}-0.245^{* *} \\
(0.109)\end{array}$ \\
\hline Country FE & Yes & Yes & Yes & Yes & Yes \\
\hline Year FE & Yes & Yes & Yes & Yes & Yes \\
\hline N. of countries & 132 & 132 & 132 & 132 & 132 \\
\hline Observations & 6,204 & 6,204 & 6,204 & 6,204 & 6,204 \\
\hline $\operatorname{AR}(1)$ & - & - & - & - & 0.000 \\
\hline $\operatorname{AR}(2)$ & - & - & - & - & 0.482 \\
\hline
\end{tabular}

Notes: The dependent variable in Columns (1) and (3) is an indicator variable equal to one if there is an onset of armed conflict ( $>25$ battle-related deaths) at time $t$. The dependent variable in Columns (2), (4) and (5) is an indicator variable equal to one if there is an ongoing armed conflict in the country at time $t . \Delta P r *$ Total is the percentage change in the price of crude oil from period $t$ - 1 to $t$, multiplied by the average share of total oil in GDP over the sample period. $\Delta P r *$ Onshore and $\Delta P r * O f f$ shore measure the percentage change in the price of crude oil from period $t$ - 1 to $t$, multiplied by the country's average share of onshore and offshore oil in GDP, respectively. The method of estimation in Columns (1)-(4) is least squares, in Column (5) system-GMM (Blundell-Bond). The values reported for AR(1) and $\operatorname{AR}(2)$ are the p-values for first- and second-order autocorrelated disturbances in the first differences equations. Standard errors are clustered at the country level. Significantly different from zero at the ${ }^{*} 90 \%$ level, ${ }^{* *} 95 \%$ level, $* * * 99 \%$ level. 
Table 3 Relative Rebel Groups Strength

\begin{tabular}{|c|c|c|c|c|}
\hline & (1) & $(2)$ & (3) & (4) \\
\hline & $\mathrm{LS}$ & LS & $\mathrm{LS}$ & $\mathrm{LS}$ \\
\hline & $\begin{array}{l}\text { Conflict } \\
\text { incidence }\end{array}$ & $\begin{array}{l}\text { Avg. rebel } \\
\text { strength }\end{array}$ & $\begin{array}{l}\text { Max. rebel } \\
\text { strength }\end{array}$ & $\begin{array}{l}\text { Number } \\
\text { rebel groups }\end{array}$ \\
\hline Rebel Strength & $\begin{array}{c}0.235^{* * *} \\
(0.021)\end{array}$ & & & \\
\hline$\Delta P r *$ Onshore & & $\begin{array}{c}0.591^{* *} \\
(0.248)\end{array}$ & $\begin{array}{c}0.688^{* * *} \\
(0.248)\end{array}$ & $\begin{array}{l}0.346^{*} \\
(0.177)\end{array}$ \\
\hline$\Delta P r * O f f$ shore & & $\begin{array}{c}-0.536^{* *} \\
(0.251)\end{array}$ & $\begin{array}{c}-0.734^{* *} \\
(0.339)\end{array}$ & $\begin{array}{l}-0.305 \\
(0.207)\end{array}$ \\
\hline Country FE & Yes & Yes & Yes & Yes \\
\hline Year FE & Yes & Yes & Yes & Yes \\
\hline N. of countries & 132 & 132 & 132 & 132 \\
\hline Observations & 6,204 & 6,204 & 6,204 & 6,204 \\
\hline
\end{tabular}

Notes: The dependent variable in Column (1) is an indicator variable equal to one if there is an ongoing armed conflict ( $>25$ battle-related deaths) in the country at time $t$. Rebel Strength measures the maximum relative strength of rebel groups in the country at time $\mathrm{t}$ (score between 0-5). The dependent variable in Columns (2) and (3) are the average relative rebel strength score and the maximum rebel strength score, relative to the government in country $i$ at time $t$, respectively. The dependent variable in Column (4) is the number of active rebel groups in country $i$ at time $t . \Delta P r *$ Onshore and $\Delta P r * O f f$ shore measure the percentage change in the price of crude oil from period $t-1$ to $t$, multiplied by the country's average share of onshore and offshore oil in GDP, respectively. The method of estimation is least squares. Standard errors are clustered at the country level. Significantly different from zero at the ${ }^{*} 90 \%$ level, $* * 95 \%$ level, $* * * 99 \%$ level. 
Table 4 Oil Price Shocks, Location of Production, and Civil War

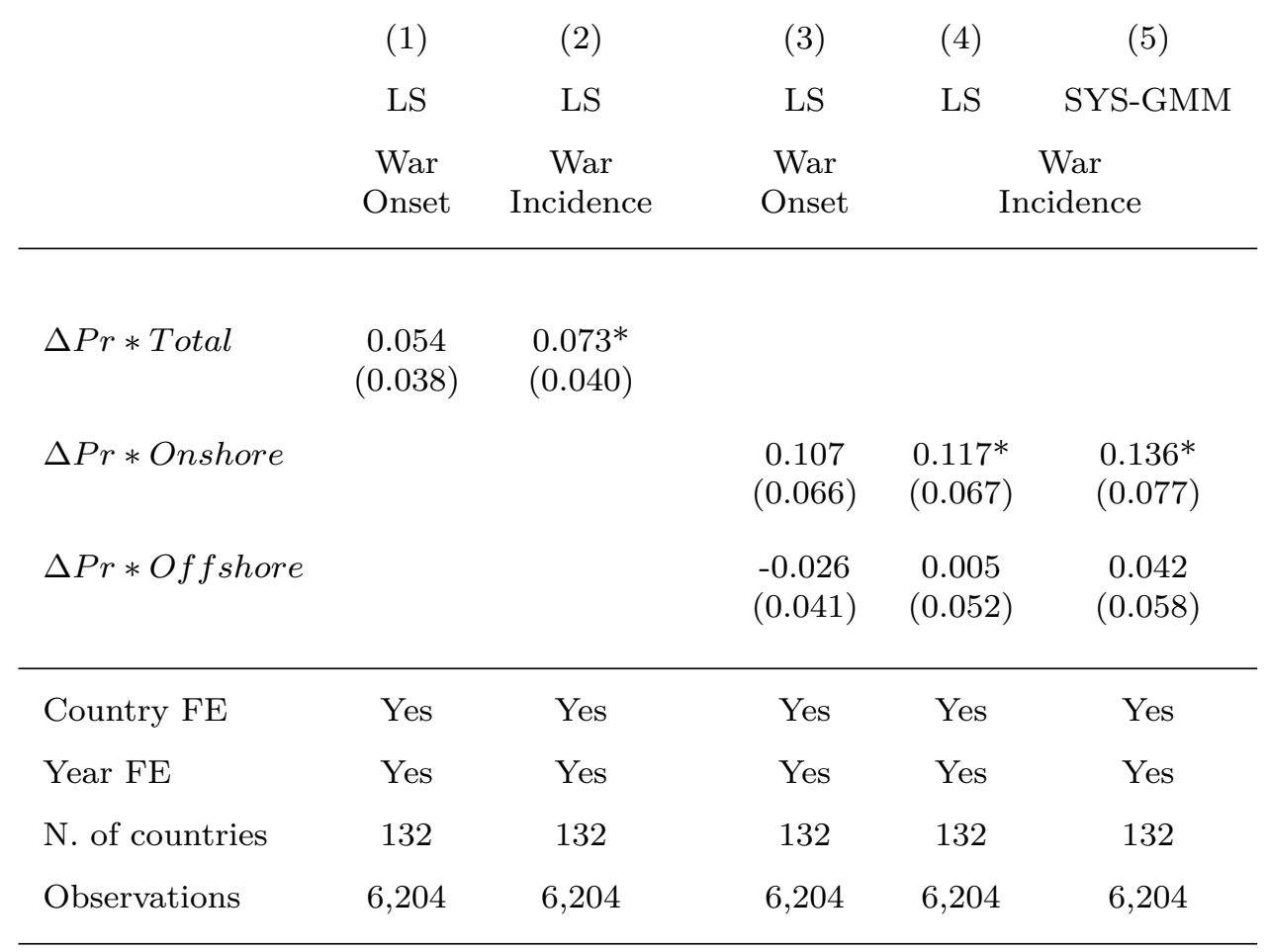

Notes: The dependent variable in Columns (1) and (3) is an indicator variable equal to one if there is an onset of war $(>1,000$ battle-related deaths) in the country at time $t$. The dependent variable in Columns (2), (4) and (5) is an indicator variable equal to one if there is an ongoing war in the country at time $t . \Delta P r *$ Total is the percentage change in the price of crude oil from period $t-1$ to $t$, multiplied by the average share of total oil income in GDP over the sample period. $\Delta P r *$ Onshore and $\Delta P r * O f f$ shore measure the percentage change in the price of crude oil from period $t-1$ to $t$, multiplied by the country's average share of onshore and offshore oil income in GDP, respectively. The method of estimation in Columns (1)-(4) is least squares, in Column (5) system-GMM (Blundell-Bond). Standard errors are clustered at the country level. Significantly different from zero at the $* 90 \%$ level, $* * 95 \%$ level, ***99\% level. 
Table 5 Civil Conflict Incidence - Alternative Specifications

\begin{tabular}{|c|c|c|c|c|c|c|}
\hline & \multicolumn{2}{|c|}{ Share $1^{\text {st }}$ year } & \multicolumn{2}{|c|}{ Country-trends } & \multicolumn{2}{|c|}{ Population weights } \\
\hline & (1) & $(2)$ & (3) & $(4)$ & $(5)$ & $(6)$ \\
\hline & $\mathrm{LS}$ & SYS-GMM & $\mathrm{LS}$ & SYS-GMM & $\mathrm{LS}$ & SYS-GMM \\
\hline$\Delta P r *$ Onshore & $\begin{array}{c}0.177^{*} \\
(0.092)\end{array}$ & $\begin{array}{c}0.172^{*} \\
(0.102)\end{array}$ & $\begin{array}{c}0.161^{*} \\
(0.087)\end{array}$ & $\begin{array}{c}0.199 \\
(0.143)\end{array}$ & $\begin{array}{c}0.188^{*} \\
(0.095)\end{array}$ & $\begin{array}{c}0.183^{*} \\
(0.110)\end{array}$ \\
\hline$\Delta P r * O f f s h o r e$ & $\begin{array}{c}-0.401^{*} \\
(0.230)\end{array}$ & $\begin{array}{c}-0.417^{*} \\
(0.234)\end{array}$ & $\begin{array}{c}-0.262^{* *} \\
(0.108)\end{array}$ & $\begin{array}{c}-0.333^{* * *} \\
(0.107)\end{array}$ & $\begin{array}{c}-0.314^{* * *} \\
(0.111)\end{array}$ & $\begin{array}{c}-0.341^{* * *} \\
(0.112)\end{array}$ \\
\hline Country FE & Yes & Yes & Yes & Yes & Yes & Yes \\
\hline Year FE & Yes & Yes & Yes & Yes & Yes & Yes \\
\hline Country Trend & No & No & Yes & Yes & No & No \\
\hline N. of countries & 132 & 132 & 132 & 132 & 130 & 130 \\
\hline Observations & 6,204 & 6,204 & 6,204 & 6,204 & 6,080 & 6,080 \\
\hline
\end{tabular}

Notes: The dependent variable throughout is an indicator variable equal to one if there is an ongoing armed conflict ( $>25$ battle-related deaths) in the country at time $t$. In Columns (1) and (2), $\Delta \operatorname{Pr} *$ Onshore and $\Delta P r * O f f$ shore measure the percentage change in the price of crude oil from period $t-1$ to $t$, multiplied by the country's share of onshore and offshore oil in GDP in the base year (1962), respectively. In Columns (3)-(6), $\Delta \operatorname{Pr} *$ Onshore and $\Delta P r * O f f$ shore measure the percentage change in the price of crude oil from period $t$ - 1 to $t$, multiplied by the average share of onshore and offshore oil in GDP over the sample period, respectively. Columns (3) and (4) add controls for country-specific linear trends, while Columns (5) and (6) add analytic weights on population size. The method of estimation in Columns (1), (3) and (5) is least squares, in Columns (2), (4) and (6) system-GMM (Blundell-Bond). Standard errors are clustered at the country level. Significantly different from zero at the $* 90 \%$ level, $* * 95 \%$ level, $* * * 99 \%$ level. 
Table 6 Small and Big Producers

\begin{tabular}{lcccccc}
\hline & \multicolumn{2}{c}{ Ex. non-producers } & \multicolumn{2}{c}{ Ex. share $<5 \%$} & \multicolumn{2}{c}{ Ex. OPEC } \\
\cline { 2 - 7 } & $(1)$ & $(2)$ & $(3)$ & $(4)$ & $(5)$ & $(6)$ \\
& LS & SYS-GMM & LS & SYS-GMM & LS & SYS-GMM \\
\hline & & & & & & \\
$\Delta P r *$ Onshore & $0.156^{*}$ & 0.168 & $0.166^{*}$ & $0.184^{*}$ & 0.195 & 0.205 \\
& $(0.092)$ & $(0.107)$ & $(0.091)$ & $(0.098)$ & $(0.132)$ & $(0.142)$ \\
$\Delta P r *$ Offshore & $-0.299^{* * *}$ & $-0.276^{* *}$ & $-0.302^{* * *}$ & $-0.313^{* * *}$ & $-0.175^{* * *}$ & $-0.139 * * *$ \\
& $(0.112)$ & $(0.128)$ & $(0.104)$ & $(0.119)$ & $(0.057)$ & $(0.052)$ \\
Country FE & Yes & Yes & Yes & Yes & Yes & Yes \\
Year FE & Yes & Yes & Yes & Yes & Yes & Yes \\
N. of countries & 87 & 87 & 83 & 83 & 125 & 125 \\
Observations & 4,089 & 4,089 & 2,183 & 2,183 & 5,661 & 5,661 \\
\hline \hline
\end{tabular}

Notes: The dependent variable throughout is an indicator variable equal to one if there is an ongoing armed conflict ( $>25$ battle-related deaths) in the country at time $t . \Delta P r *$ Onshore and $\Delta \operatorname{Pr} *$ Offshore measure the percentage change in the price of crude oil from period $t-1$ to $t$, multiplied by the country's average share of onshore and offshore oil in GDP, respectively. Columns (1) and (2) exclude non-oil producers, Columns (3) and (4) exclude all country-year observations where total production represents less than $5 \%$ of GDP, while Columns (5) and (6) exclude OPEC member countries. The method of estimation in Columns (1), (3) and (5) is least squares, in Columns (2), (4) and (6) system-GMM (Blundell-Bond). Standard errors are clustered at the country level. Significantly different from zero at the $* 90 \%$ level, $* * 95 \%$ level, $* * * 99 \%$ level. 
Table 7 Breaking by Quality of the Data

\begin{tabular}{|c|c|c|c|c|c|c|}
\hline & \multicolumn{2}{|c|}{$\geq 1 / 2$ Share obs. } & \multicolumn{2}{|c|}{$\underline{\text { Obs. before } 1986}$} & \multicolumn{2}{|c|}{$\leq 25 \%$ Difference } \\
\hline & (1) & $(2)$ & $(3)$ & (4) & $(5)$ & (6) \\
\hline & LS & SYS-GMM & LS & SYS-GMM & $\mathrm{LS}$ & SYS-GMM \\
\hline$\Delta P r *$ Onshore & $\begin{array}{c}0.195^{*} \\
(0.114)\end{array}$ & $\begin{array}{c}0.191 \\
(0.133)\end{array}$ & $\begin{array}{c}0.189^{*} \\
(0.114)\end{array}$ & $\begin{array}{c}0.183 \\
(0.131)\end{array}$ & $\begin{array}{c}0.236^{* *} \\
(0.118)\end{array}$ & $\begin{array}{c}0.197^{*} \\
(0.107)\end{array}$ \\
\hline$\Delta P r *$ Offshore & $\begin{array}{c}-0.317^{* *} \\
(0.125)\end{array}$ & $\begin{array}{c}-0.370^{* * *} \\
(0.118)\end{array}$ & $\begin{array}{c}-0.322^{* *} \\
(0.125)\end{array}$ & $\begin{array}{c}-0.373^{* * *} \\
(0.120)\end{array}$ & $\begin{array}{c}-0.476^{* *} \\
(0.227)\end{array}$ & $\begin{array}{c}-0.333 \\
(0.210)\end{array}$ \\
\hline Country FE & Yes & Yes & Yes & Yes & Yes & Yes \\
\hline Year FE & Yes & Yes & Yes & Yes & Yes & Yes \\
\hline N. of countries & 105 & 105 & 102 & 102 & 132 & 132 \\
\hline Observations & 4,935 & 4,935 & 4,794 & 4,794 & 3,232 & 3,232 \\
\hline
\end{tabular}

Notes: The dependent variable throughout is an indicator variable equal to one if there is an ongoing armed conflict ( $>25$ battle-related deaths) in the country at time $t . \Delta \operatorname{Pr} *$ Onshore and $\Delta \operatorname{Pr} *$ Offshore measure the percentage change in the price of crude oil from period $t$-1 to $t$, multiplied by the country's average share of onshore and offshore oil in GDP, respectively. Columns (1) and (2) exclude countries for which the average share of oil production is calculated over less than half of the sample-years. Columns (3) and (4) restrict the sample to countries for which we observe onshore and offshore shares at least once before 1986. Columns (5) and (6) exclude observations with a discrepancy between the total share of oil in GDP calculated from our data and the corresponding value from the WDI of more than $25 \%$ of total production. The method of estimation in Columns (1), (3) and (5) is least squares, in Columns (2), (4) and (6) system-GMM (Blundell-Bond). Standard errors are clustered at the country level. Significantly different from zero at the $* 90 \%$ level, ${ }^{* *} 95 \%$ level, $* * * 99 \%$ level. 


\section{Centre for Applied Macro - and Petroleum economics (CAMP)}

will bring together economists working on applied macroeconomic issues, with special emphasis on petroleum economics.

BI Norwegian Business School

Centre for Applied Macro - Petroleum economics (CAMP) $\mathrm{N}-0442$ Oslo

http://www.bi.no/camp 